\section{B A Institute of \\ YK Business Administration \\ 六下 \\ Karachi \\ Leadership and Ideas for Tomorrow}

Article 3

Volume 8 Issue 1 January-June 2013

$1-1-2013$

\title{
Interest rate sensitivity and stock returns
}

Mohsin R. Khan

Bahria University, Islamabad, Pakistan

Zahid Mahmood

Bahria University, Islamabad, Pakistan

Follow this and additional works at: https://ir.iba.edu.pk/businessreview

Part of the Finance and Financial Management Commons

(c) (i)

This work is licensed under a Creative Commons Attribution 4.0 International License.

\section{Recommended Citation}

Khan, M., \& Mahmood, Z. (2013). Interest rate sensitivity and stock returns. Business Review, 8(1), 20-33. Retrieved from https://doi.org/10.54784/1990-6587.1214 


\title{
ARTICLE
}

\section{Interest Rate Sensitivity and Stock Returns}

\author{
Mohsin R. Khan \\ Bahria University, Islamabad, Pakistan \\ Dr. Zahid Mahmood \\ Bahria University, Islamabad, Pakistan
}

\begin{abstract}
This paper investigates the sensitivity of interest rate to stock return of financial institutions traded at Karachi Stock Exchange. Two Index Model of Stone and Bernell(1974) have been used to test the proposition of the present study. Three different portfolios of financial institutions have been examined against sensitivity of actual and unanticipated interest rates. Repo rate/Policy rate instead of t-bill rate is used for the proxy of interest rate. The data is collected from twenty nine financial institutions covering the time period from 2004 to 2011. Unit root test, co integration and error correction mechanism have been checked before proceeding to Two Index Model. For unanticipated interest rate risk ARIMA is proposed using Box Jenkins methodology. The findings of present study shows that stock returns of financial institution demonstrates positive sensitivity to market index and are statistically significant. However, sensitivity to interest rate is negative and statistically insignificant.
\end{abstract}

JEL Code: E44 Financial markets and macro economy

Key words: Karachi Stock Exchange, Stock return at KSE

\section{Introduction}

Interest rates have a direct impact when it comes to bond market. However, interest rate sensitivity to stock return is not consistent or direct (Reilly and Brown, 2005). It is argued the actual sensitivity between stock prices and interest rate is negative i.e. increase in interest rates cause stock price to decrease, suppressing the rate of returns. However, this sensitivity is not always consistent (Titman \& Warga, 1989). Interest rates impact on stock return can be time varying and also subject to the nature of business (Joseph \& Vezos 2006; Park \& Choi 2011). Similarly, some industries may react more to interest rates because of their financial structure than others. As Khawaja (1995) argues interest rate is a tool in the hands of the government to regulate financial markets. The Neoclassical theory of interest states that in case of increase in interest rates loan demanded by an entrepreneur becomes expensive causes a shrink in investment activity and stock return. When a rate of interest is high investor will obtain fewer loans and subsequently invest less and vice versa (Khawaja 1995). 
The key purpose of this paper is to investigate how stock return of financial institution in Pakistan responds to interest rates sensitivity as well to stock market itself. In the context of Pakistan Stock Market, it is worth exploring this phenomenon because interest rates in Pakistan are quiet high among Asian financial markets (Allen, 2012). The interest rates sensitivity and stock return at KSE is important because it will give a hint as to how an investor at Karachi Stock Exchange (KSE) responds to change in the rate of interest. The issue of interest rate sensitivity and stock return is important with reference to Pakistan because Pakistan economy is facing double digit inflation since the last five years. Government recently reduces the interest rates aiming to spur growth in financial markets (Khan, 2011).

This proposition was tested using relevant econometric techniques i.e. unit root test has been applied to check that the time series was stationery, multi-co-linearity between variables and co- integration has been checked to avoid spurious regression. For unanticipated interest rates ARIMA Model has been used in two index model in the context of Pakistan stock exchange market. Stone Two index model previously have been applied on bank stock return (Brewer \& Lee 1990; Flannery \& James 1984), and on insurance stock return Park and (Choi, 2011).

However, the scope of the present study has been extended by using two-index model for financial institutions including banks, insurance companies, and financial institutions (Annex A). Furthermore, repo rate ${ }^{1}$ for proxy of interest rate sensitivity is used instead of t-Bills rates used by previous studies (Brewer \& Lee 1990; Schrand 1997; Karam \& Mittal 2011).

The remainder of this paper is organized as follows. The first part provides the review of relevant literature. The second and third part provides the procedure followed by data description collection and analysis. The fourth part provides discussion and fifth and final section provides conclusion of present study.

\subsection{Literature Review}

Two index model shows that return of underlying security is sensitive to interest rate change and stock market index (Stone \& Bernell, 1974). Its variations have been used widely by researchers in evaluating interest rate sensitive securities. Stone and Bernell (1974) set the trend by postulating that the return of security is highly affected by interest rate as well as market forces itself. This conviction opens a new debate and most of the empirical studies on two index models are consistent with the finding of original research of Stone and Bernell(1974) and found spastically significant sensitivity between stock return and interest rate (Flannery \& James 1984; Brewer \& Lee 1990; Schrand 1997; Park \& Choi 2011).

While checking the sensitivity of stock return to interest rates, Stone and Bernell (1974) have recommended two variables that can predict any change in stock return i.e. interest rate and stock market index. However, further studies have checked this sensitivity by adding more variables to the original model. Joseph and Vezos (2006) used exchange rate besides interest rates

${ }^{1}$ State Bank of Pakistan reverse repo rate (also known as policy rate or discount rate) is the rate at which banks can borrow from SBP on an overnight basis. 
to capture sensitivity and found that return of stocks shows mix trend to interest rate change. Sensitivity is also checked by Lee (1992) including inflation and real activity. Using Vector Auto regression (VAR), he found little evidence stock return sensitivity to interest rates. Consistent with Lee (1992) study Titman and Warga (1989) also used inflation and interest rates to measure sensitivity of stock return. However, they conclude that unanticipated interest rates are positively related to stock return. By using GARCH model sensitivity of insurance company's stock return to interest rate risk is check by (Elijah et al. 2007), they found that sensitivity of stock return to long term interest rates is statistically significant, rather than short term. Chancharoenchai et al.(2005) also support the significant impact of interest rate sensitivity to stock return for different countries.

While using two-index model, different interest rates have been used by researchers. Flannery and James (1984) have used three different interest rates to measure the sensitivity of bank stock returns; they found that all proxies for interest rates are statistically significant for explaining stock return sensitivity to interest rates. Brewer and Lee (1990) have used t-bills for the unanticipated interest rate risk to the sensitivity of bank stock return; they also found statistically significant relationship between stock return and interest rates.

Six different interest rates have been used by Park and Choi (2011) including three month t-bills to 30 year t-security rate, they believed that stock return of insurance companies and interest rate sensitivity were negativity related to portfolio return, and positively related to different time periods.

The actual sensitivity between interest rate and stock market is negative i.e. increase in interest rate because a decrease in stock prices (Reilly and Brown 2005). Plethoras of studies have empirically tested this sensitivity but the evidence is mixed. It was found that there is negative sensitivity between stock return and interest rate (Liu \& Shrestha 2008; Chancharoenchai et al. 2005; Elijah et al. 2007) while at the same time Titman and Warga (1989) found a positive sensitivity between interest rates and stock prices. However, Titman and Warga (1989) conclude that the generalization of study is limited as the context of study was different. In one instance Akella and Greenbaum (1992) found that stock return are extremely sensitive to unanticipated change in interest rate and a unit change in t-Bills triggers eight fold change in stock return.

The interest rate sensitivity to stock return can also be subject to causality. Causal relationship appears when dependant variable is affected by independent variable but at the same time also affects them. When this sort of relationship exists between variables, VAR is applicable (Gujarati 1978). Thorbecke (2004) estimated VAR to check how stock market sensitivity to change in monetary policy and concluded that exposure to monetary policy can reduce stock return. Another study by Laopodis (2009) found that stock market does not necessary follow the fundamentals and respond to interest rates.

Generally most time series are non stationary and sometime tilted towards volatility clustering that means periods of large swings. The stock prices, interest rates, exchange rates and inflation particularly shows high volatility (Asteriou \& Hall 2007). If time series shows such trends (Engle, 1982), ARCH family of models comes to rescue the scenario. Most of the studies which have checked the sensitivity between interest rate and stock return using $\mathrm{ARCH}$ and GARCH family of models found a negative sensitivity between interest rates and stock prices 
(Joseph \& Vezos 2006; Elijah et al. 2007; Liu \& Shrestha 2008; Chancharoenchai et al. 2005; Lunde \& Timmermann 2004).

Research was also conducted to check the sensitivity on bank stock returns to interest rates (Brewer \& Lee 1990;Joseph \& Vezos 2006). Whereas Elijah et al. (2007) worked on insurance companies and overall market reaction was tested in response to interest rates. Liu \& Shrestha (2008) have found statistically significant results. Park \& Choi (2011) and Ehrmann \& Fratzscher (2004) have found that interest rate sensitivity on stock returns can also be time varying. They found that industrial sectors that are cyclical and capital intensive are more receptive to interest rate change.

Based on the above discussion, it can be concluded that causal relationship is evident from all the theories incorporating interest rates sensitivity to stock return. Theoretical framework in this study remains same as proposed by two index model i.e. deduction base causal relationship have been observed. However conceptual framework has been altered from the original study and repo rate instead of t-bill rate has been incorporated for this study to broaden the scope of analysis. Figure (1) explains the theoretical framework of the subject under investigation.

Figure 1

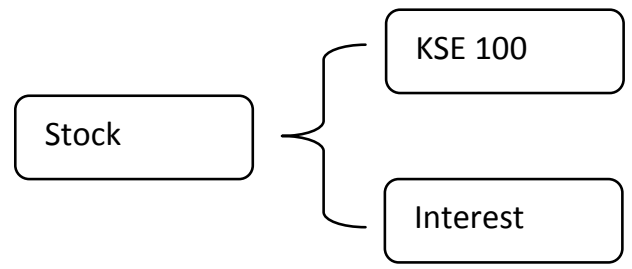

The following hypothesis has been postulated as follows:

$H_{1}$ Stock returns of financial institutions are not interest rate sensitive at KSE.

$H_{0}$ Stock returns of financial institutions are interest rate sensitive at KSE.

\subsection{Procedure}

The procedure adopted to achieve the set objective of the present study is divided into two folds. The first part discusses the sources of data and the models applied to check the proposition of current study. The second part deals with the econometric procedures necessary before proceeding to estimating the Regression models.

\subsection{Data source:}

The date source of present study comprises of stock market return of financial institutions, KSE 100 index return and interest rates. This data collection approach is consistent with two factor model (Stone \& Bernell 1974). Monthly data for KSE 100 index from January 2004 to November 2011 is used to calculate market return comprising 94 data points. Monthly market 
return from $\mathrm{KSE}$ is calculated using $\left(\mathrm{CP}-\mathrm{CP}_{\mathrm{t}-1}\right) / \mathrm{CP}_{\mathrm{t}-1}$, where $\mathrm{CP}$ is closing price of index at time $t$. The proxy for interest rate change is used for SBP Repo rate which is also called discount rate. Monthly weighted average return of stock has been taken from KSE. Total 29 companies divided in to 3 portfolios of return have been estimated.

The model below (1) is based on Stone and Bernell(1974) two index model. This model incorporates the sensitivity of both stock market and interest rate on the underlying security. Three portfolios of financial institution have been used to capture the sensitivity of interest rates on stock return. Portfolio-A comprise of banks, portfolio-B comprise of Insurance companies and Portfolio$\mathrm{C}$ consist of financial service providing companies. The sensitivity of stock return was captured by equation as follows.

$$
R_{j t}=\alpha_{j}+\beta_{M j} R_{M t}+\beta_{I j} R_{I t}+\varepsilon_{j t}
$$

Where $R_{j t}$ is portfolio return at time t. $R_{M t}$ is market return i.e. return on KSE 100 index at time t. $R_{I t}$ measures change in interest rates over the time t. $\beta_{M j}$ and $\beta_{I j}$ are beta coefficients which measures effect of change in market and interest rates respectively on the specified portfolio.

For unanticipated interest rate generally family of ARCH and GARCH models are applied Elijah et al.(2007). However a more appropriate is to go for testing ARCH effect and then proceed to next step. This step has been performed consistent with Breusch-Pagon test. From equation (1) OLS regression on portfolio $\mathrm{A}, \mathrm{B}$ and $\mathrm{C}$ have been run and residuals $\hat{u}_{t}$ obtain. Then auxiliary regression of square residuals $\left(\widehat{u}_{t}^{2}\right)$ was run by using following equation.

$$
\widehat{u}_{t}^{2}=\gamma_{0} \hat{u}_{t-1}^{2}+\ldots .+\gamma_{q} \hat{u}_{t-q}^{2}+w_{t}
$$

Under the null hypothesis of heteroskedasticity $\gamma_{0}=\gamma_{1}=\cdots=\gamma_{q}$ and rejection of null hypothesis means ARCH effects are found. For our all three models results shows acceptance of null hypothesis of homoskedasticity and found no ARCH effect Asteriou and Hall (2007).

After checking for ARCH effect and accepting $H_{0}$, for unanticipated interest rate ARIMA models were proposed. An ARIMA model has been selected by Box-Jenkinss approach of parsimony i.e. model has been selected with minimum number of parameters to be estimated Asteriou and Hall (2007). ARIMA $(0,0,1)$ was used for unanticipated interest rate which is purely MA (q) models. For checking the effect of unanticipated interest rate on stock return following equation was used:

$$
R_{j t}=\alpha_{j}+\beta_{M j} R_{M t}+\beta_{I j} U R_{I t}+\varepsilon_{j t}
$$

Where $U R_{I t}$ is used for unanticipated interest rate risk. 


\subsection{Data description and analysis}

Before proceeding to estimate regression analysis for equation (1) and (2), first step is generally to check the stationary of time series (Gujarati 1978). Graphical representation is usually the first step. Figure (2) depict the trend around all the time series.

Fig. 2
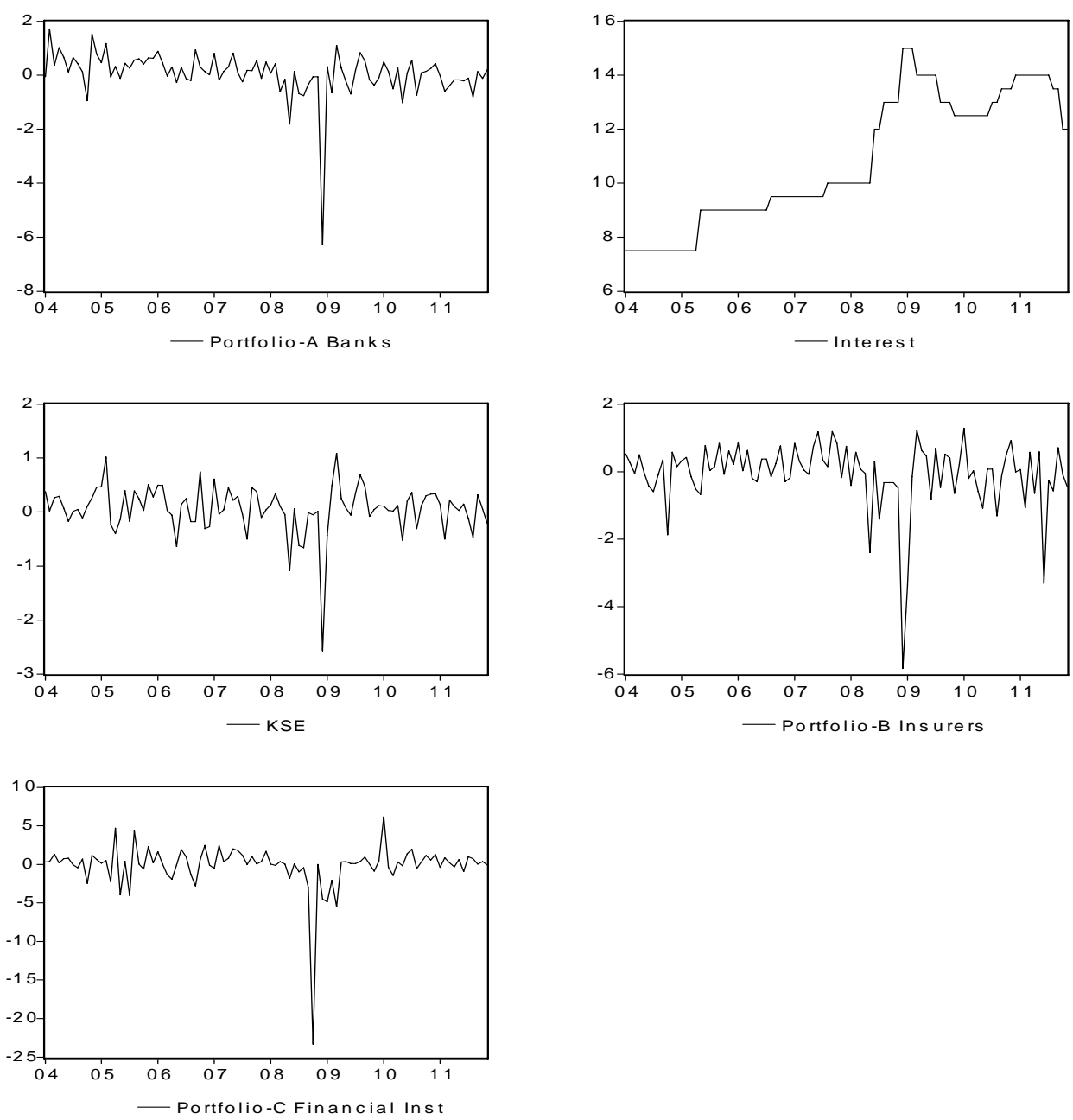

It is evident that except for inflation all series seems to be stationary. The time series demonstrate that mean and variants are not constant over time. However more formal way is to use statically test to check for stationary in data. One of the most widely used test to check stationary or non stationary of data is unit root test. 
Dickey and Fuller (1981) methodology has been used to check if the series for regression was stationary. They propose a test which includes extra lack terms of dependant variables in order to determine the serial correlation. The lagged values were chosen for AIC for ADF test the specification are as follows.

$$
\Delta y_{t}=a_{0}+\beta y_{t-1}+\sum_{t=1}^{p} \gamma i y_{t-1}+u_{t}
$$

Where $y_{t}$ the series to check for unit is root and $p$ is the number of lagged differences. The results are given in table (1). If ADF test rejects Null hypothesis means time series is stationary. For variable under consideration it is clear that only interest rates are non stationary.

Table - I

ADF Test (Unit root test)

$\begin{array}{lllll}\text { Variables } & \text { ADF test } & & \text { Comments } & \text { Order of integration } \\ \text { Inflation } & -1.5056 & & \text { Failed to reject } H_{0} & \mathrm{I}(1) \\ \text { D(Inflation) } & -4.9275 & * & \text { Reject } H_{0} & \mathrm{I}(0) \\ \text { KSE } & -5.6443 & * & \text { Reject } H_{0} & \mathrm{I}(0) \\ \text { Banks } & -4.8563 & * & \text { Reject } H_{0} & \mathrm{I}(0) \\ \text { Insurers } & -5.4632 & * & \text { Reject } H_{0} & \mathrm{I}(0) \\ \text { Fin inst } & -3.9483 & * & \text { Reject } H_{0} & \mathrm{I}(0)\end{array}$

Notes: *,** and *** indicate rejection of null hypothesis of

Non-stationary at 1, 5, and 10 percent. Significant level.

Critical value obtain from Fuller (1976) are $-3.5022,-2.8928$ and

-2.8928 .

\subsection{Discussion}

Three proposed actions have been suggested after findings the stationary time series (Asteriou \& Hall 2007; Gujarati 1978) . If dependent and independent variables under study are stationary we may proceed towards applying normal regression. Second if both variables are integrated of same orders then it is likely that they are co integrated and have a long term relationship. This will lead to check co integration of residuals and error correction mechanism. Third option is that if dependent and independent variables are integrated of different orders it may be assumed that there will be no co integration between them. In case of present study interest rates and portfolio returns were integrated in different order see Table (1) therefore this study can assume that there is no co integration. However doing a formal test confirms no co integration. 
Residuals have been taken from applying equation (1) on three portfolios. The form of DF test is the following.

$$
\Delta \hat{e}_{t}=a_{1} \hat{e}_{t-1}+\sum_{i=1}^{n} \delta i \Delta \hat{e}_{t-1}+v_{t}
$$

DF test was applied on residuals taken from equation (1) to check if they are integrated. Results are explained in table (2), (3) and (4) (Annex B). Table (2), (3) and (4) results shows acceptance of $H_{0}$ of no-co integration. By examining the co integration the variables seems to be weak co integrated and hence problem of multi-co-linearity can be ignored (Gujarati 1978).OLS regression was finally run for equation (1) and (2) on all portfolios.

As the results of unanticipated interest rates and actual are quite similar there for we limit our discussion to equation (1) only. For banks, there is a bleak difference between the unanticipated interest rate and actual one. Moreover the KSE coefficient is also very significant. Defining the returns of bank Table (5) the model specification shows that there is a positive relationship between market risk and bank return. The results are statistically significant it implies that $1 \%$ increase in KSE 100 index will lead to $1.4 \%$ return in bank stock. This result shows that bank stocks are very receptive to overall market. It also concludes that investor can maximize their return while keeping a pace with the market i.e. if KSE index is rising; it will also boost the returns of banks stock. As far as the interest rate is concerned, results show a negative relationship between interest rate and stock returns. In case of banks, a 1\% increase in interest rate will decrease bank stock by $.18 \%$ and the results are statistically insignificant. The $R^{2}$ shows that $61 \%$ of variation in banks stocks are due to these two variables.

Table - II Regression results equation (1) on Portfolio-A Banks

\begin{tabular}{lllll}
\hline Variable & Coefficient & Std. Error & t-Statistic & Prob. \\
\hline C & -0.0059 & 0.057171 & -0.103156 & 0.918100 \\
KSE & 1.43041 & 0.139746 & 10.23578 & 0.000000 \\
Inflation & -0.1838 & 0.145443 & -1.263678 & 0.209600 \\
& & & \\
R-squared & 0.61476 & Mean dependent var & 0.068085 \\
Adjusted R-squared & 0.60629 & S.D. dependent var & 0.861084 \\
S.E. of regression & 0.5403 & Akaike info criterion & 1.638008 \\
Sum squared resid & 26.565 & Schwarz criterion & 1.719177 \\
Log likelihood & -73.986 & F-statistic & 72.60676 \\
Durbin-Watson stat & 2.11963 & Prob(F-statistic) & 0.000000 \\
& \multicolumn{5}{l}{} \\
Dependent Variable Banks & \multicolumn{5}{l}{} \\
\hline
\end{tabular}


For insurance companies results are similar to banks Table (6) where the beta coefficient is statistically significant for market proxy and insignificant for interest rates. It implies that insurance companies respond to interest rate and market in the same fashion as bank. However, results of $R^{2}$ are less robust than that of bank. Only 50\% of variation in insurance stock returns is explained by models.

Table - III

Regression results equation (1) on Portfolio-B Insurance companies

\begin{tabular}{lllll}
\hline Variable & Coefficient & Std. Error & t-Statistic & Prob. \\
\hline $\mathrm{C}$ & -0.1816 & 0.074505 & -2.437088 & 0.016800 \\
KSE & 1.64081 & 0.182115 & 9.009747 & 0.000000 \\
Inflation & 0.03599 & 0.18954 & 0.18986 & 0.849800 \\
& & & \\
R-squared & 0.51955 & Mean dependent var & -0.08489 \\
Adjusted R-squared & 0.50899 & S.D. dependent var & 1.004839 \\
S.E. of regression & 0.70411 & Akaike info criterion & 2.167632 \\
Sum squared resid & 45.1152 & Schwarz criterion & 2.248801 \\
Log likelihood & -98.879 & F-statistic & 49.20298 \\
Durbin-Watson stat & 1.94939 & Prob(F-statistic) & & 0.000000
\end{tabular}

Dependent Variable Insurance companies

Surprising results are found for financial institutions Table (7) model variables are statistically insignificant for explaining returns of financial institution. A $1 \%$ change in KSE index triggers $1.18 \%$ change in returns of financial institution and only $02 \%$ change can be witness in return due to $1 \%$ change in interest rate. Model specification to fit the data i.e. $R^{2}$ is also very low and only $03 \%$ which is negligible change in financial institution is due to variables of the model.

Table - IV

Regression results equation (1) on Portfolio-C Financial services

\begin{tabular}{lllll}
\hline Variable & Coefficient & Std. Error & t-Statistic & Prob. \\
\hline $\mathrm{C}$ & -0.2356 & 0.315434 & -0.747044 & 0.457000 \\
KSE & 1.1862 & 0.771032 & 1.538462 & 0.127400 \\
Inflation & 0.02611 & 0.802465 & 0.032538 & 0.974100 \\
& & & \\
R-squared & 0.03057 & Mean dependent var & -0.16575 \\
Adjusted R-squared & 0.00926 & S.D. dependent var & 2.994928 \\
S.E. of regression & 2.98103 & Akaike info criterion & 5.053811
\end{tabular}


Business Review - Volume 8 Number 1

$\begin{array}{llll}\text { Sum squared resid } & 808.676 & \text { Schwarz criterion } & 5.134980 \\ \text { Log likelihood } & -234.53 & \text { F-statistic } & 1.434537 \\ \text { Durbin-Watson stat } & 1.85373 & \text { Prob(F-statistic) } & 0.243561\end{array}$

Dependent Variable Financial services

Over all these results show that interest rate sensitivity to return of financial institution are statistically insignificant. Therefore it may reject $H_{0}$ i.e. significant impact of interest rates on stock return. This means fluctuation in interest rates will not affect the return of financial institution of KSE. Several others variables must be incorporated to check the return of stocks.

\subsection{Conclusion}

The present study investigates the interest rate sensitivity of stock return traded at KSE. Actual and unanticipated interest rates have been taken to check this sensitivity. The present study attempts to employ the two-index model developed by Stone and Bernell(1974) to measure the stock return at KSE. Secondly, repo rate instead of traditional t-bill rate (Akella \& Greenbaum 1992; Flannery \& James 1984) is used as a proxy of interest rate.

This approach is consistent with previous studies on two index model of Park and Choi (2011). This study found a negative relationship between stock return and interest rate. For return of financial institution and insurance companies, a positive sensitivity to interest rates has been observed. However for financial institution and insurance companies the results are statistically insignificant. The finding may not be generalized as the time period covered is eight years only and the sample was small and constitutes only 29 companies out of 100 companies.

Two major inferences can be drawn from the study on the face of it. It seems that any change in interest rate by government to regulate financial market and to bring bullish activity in stock market may fall short. Therefore investors who seem to take advantage from interest rate reduction might not get benefit. Secondly reducing interest rate may have some other objective to be achieved by government that is a government mired in debt may reduce interest rate for debt servicing.

It also shows that that there is a need for further studies and our models could be used which includes other economic variables and explained variation in stock returns. 践

\section{References}

Akella,S.R. \& Greenbaum, S.I. (1992). Innovations in Interest Rates, Duration Transformation, and Bank Stock Returns. Journal of Money, Credit and Banking, 24(1): 27-42.

Asger,L. \& Timmermann, A. (2004). Duration Dependence in Stock Prices: An Analysis of Bull and Bear Markets. Asger Lunde and Allan Timmermann , 22(3): 253-273 
Asteriou,D. \& Hall,S. (2007). Applied Econometrics. Revised edition, New York, Palgrave Macmillan.

Brewer III,E, \& Lee,F.C. (1990). An Intracyclical Analysis of the Risk Sensitivity of Bank Stock

Returns. Quarterly Journal of Business and Economics , 29(4): 125-143.

Brewer III,E.,Carson,M.J.,Elyas,E.,Mansur,I., et al. (2007). Interest Rate Risk and Equity Values of Life Insurance Companies: A GARCH-M Model. The Journal of Risk and Insurance , 74(2): 401-423.

Chancharoenchai, K., Dibooglu,S.,Mathur,I.(2005). Stock Returns and the Macroeconomic Environment Prior to the Asian Crisis in Selected Southeast Asian Countries. Emerging Markets Finance \& Trade , 41(4): 38-56.

Ehrmann, M. \& Fratzscher, M. (2004). Taking Stock: Monetary Policy Transmission to Equity Markets. Journal of Money, Credit and Banking, 36(4): 719-737.

Engle,R.F. (1982). Autoregressive conditional Heteroskedasticity with estimates of the variance of U.K Inflation. Econometrica, 50(4): 987-1008.

Flannery, M. J.\& James,C.M. (1984). The Effect of Interest Rate Changes on the Common Stock Returns of Financial Institutions. The Journal of Finance, 39(4): 1141-1153.

Gujarati, D. N. (1978). Basic Econometrics. $4^{\text {th }}$ edition, McGraw Hill

Joseph, N. L.\& Vezos,P. (2006). The sensitivity of US banks' stock returns to interest rate and exchange rate changes. Managerial Finance, 32(2): 182-199.

Khawaja, A. H. (1995). Economic Theory. Karachi, $3^{\text {rd }}$ edition, Karachi, A.H Publishers. Karam,P. \& Mittal, R. (2011). Impact of macroeconomic indicators on Indian capital markets. The Journal of Risk Finance, 12(2): 84-97.

Khan, M. R. (2011, November 11). Easing intyerest Rate a solution ? Diplomatic circle Islamabad, pp. 32-33.

Laopodis, N. T. (2009). Real investment and stock prices in the USA. Managerial Finance, 35(1) : 182-199.

Lee,B.S. (1992). Causal Relations Among Stock Returns, Interest Rates, Real Activity, and Inflation. The Journal of Finance , 47(4): 1591-1603.

Liu,M.\& Shrestha,K.M. (2008). Analysis of the long-term relationship between macroeconomic Chinese stock market using heteroscedastic cointegration. Managerial Finance , 34(11): 744-755.

Park, J. \& Choi, P.B. (2011). Interest rate sensitivity of US property/liability insurer stock returns. Managerial Finance , 7(3),134-150. 
Reilly,F.K \& Brown, K. C. (2005). Investment Analysis and Portfolio Managemet . $8^{\text {th }}$ edition. Indiana.

Schrand, C. M. (1997). The Association between Stock-Price Interest Rate Sensitivity and Disclosures about Derivative. The Accounting Review , 72(1): 87-109.

Stone \& Bernell, K. (1974). Systematic Interest Rate Risk in a Two-Index Model of Returns. Journal of Financial and Quantitative Analysis , 709-721.

Thorbecke, W. (2004). On Stock Market Returns and Monetary Policy. The Journal of Finance , 52(2): 253-273.

Titman, S. \& Warga,A. (1989). Stock Returns as Predictors of Interest Rates and Inflation. The Journal of Financial and Quantitative Analysis , 24(1): 47-58.

Mack, A. (2012). Interest rates in Pakistan.http://www.unescap.org/stat/data/syb2009/24-Inflationinterest-rates.asp

"If you have made mistakes, even serious ones, there is always another chance for you. What we call failure is not the falling down but the staying down."

Mary Pickford 


\section{Annex A}

Portfolio-A Banks Portfolio-B Insurance
Portfolio-C Financial services

F. Nat.Equities

Orix Leasing

Saudi Pak Leasing

AMZ Ventures

Ist.Dawood Bank

Ist.Capital Sec.

Sec. Inv. Bank

Dawood Cap.Managemen

JOVC

PAKRIJSIDDIQ

United Bank Ltd

Grays Leasing

Annex B

Table - II

Unit root test on residuals Portfolio-A

$\begin{array}{lcll}\text { Variables } & \text { ADF test } & \text { Comments } & \text { order of integration } \\ \text { Residuals of co-integration equation } & -4.126735 & \text { Accept } H_{0} & \mathrm{I}(0) \\ \text { Note: Banks as dependent variable; accept at } 1 * \text { level } & \\ \text { Critical value obtain from Fuller (1976) are }-3.5031,-2.8932 \text { and - and }-2.5834\end{array}$

Table - III

Unit root test on residuals Portfolio-B

Variables ADF test Comments order of integration

$\begin{array}{llll}\text { Residuals of co-integration equation } & -4.55499 & \text { Accept } H_{0} & \mathrm{I}(0)\end{array}$

Note: Insurance companies as dependent variable; accept at $1 *$ level

Critical value obtain from Fuller (1976) are -3.5031, -2.8932 and - and -2.5834. 
https://ir.iba.edu.pk/businessreview/vol8/iss1/3

DOI: https://doi.org/10.54784/1990-6587.1214

Business Review - Volume 8 Number 1

January - June 2013

Table - IV

Unit root test on residuals Portfolio-C

Variables ADF test Comments order of integration

Residuals of co-integration equation $\quad-4.641426 \quad$ Accept $H_{0} \quad \mathrm{I}(0)$

Note: Financial services as dependent variable; accept at $1 *$ level

Critical value obtain from Fuller (1976) are -3.5031, -2.8932 and - and -2.5834.

"Age does not protect you from love. But love, to same extent, protects you from age."

Jeanne Morean 